\title{
Regulation of proliferation and differentiation of Luxi bovine intramuscular preadipocytes by propionate $^{*}$
}

\author{
R. Wan, J. Ding, Z.M. Zhou, L.P. Ren and Q.X. Meng' \\ State Key Laboratory of Animal Nutrition, Beef Cattle Research Centre, \\ College of Animal Science and Technology, China Agricultural University \\ Beijing 100094, P.R. China
}

\begin{abstract}
The purpose of the present study was to investigate the regulation of propionate on the proliferation and differentiation of cultured intramuscular preadipocytes from three adult Luxi Yellow steers. The flow cytometry, lipid droplets stained by oil red $\mathrm{O}$, and cytoplasmic fat content were detected after cultured cells were treated with different concentrations of propionate $(0,1,3,6 \mathrm{mM})$. The results showed that the separated cells were highly homogeneous and proliferative. Propionate $(1 \mathrm{mM})$ did not significantly affect $(\mathrm{P}>0.05)$ the cell proportion of phase $\mathrm{G} 0 / \mathrm{G} 1$, but remarkably $(\mathrm{P}<0.05)$ increased the proportion of phase $\mathrm{S}+\mathrm{G} 2 / \mathrm{M}$. However, the cell proportion significantly increased $(\mathrm{P}<0.05)$ in the phase $\mathrm{G} 0 / \mathrm{G} 1$, and decreased $(\mathrm{P}<0.05)$ in the phase $\mathrm{S}+\mathrm{G} 2 / \mathrm{M}$ when the concentration of propionate reached to $6 \mathrm{mM}$. When the confluent intramuscular preadipocytes were treated with insulin $(10 \mu \mathrm{g} / \mathrm{ml})$ and dexamethasone $(0.25 \mu \mathrm{M})$, small lipid droplets began to appear, and their number rapidly increased around the nuclei on day 6 . Subsequently, when the confluent intramuscular preadipocytes were treated with propionate, significant accumulation of lipid droplets was observed on day 6 , and lipid accumulation extent was dependent on the dose of propionate. In addition, cytoplasmic fat contents of cultured preadipocytes treated with propionate $(1,3,6 \mathrm{mM})$ for 6 days were 1.5, 2, and 2 times higher than those of control group (without propionate addition). In conclusion, the present study confirmed that there were indeed functionally active preadipocytes existing in the muscle of Chinese adult Luxi steers. Propionate may play an important physiological role in regulation of adipogenesis and stimulation of proliferation and differentiation of Luxi bovine intramuscular preadipocytes.
\end{abstract}

KEY WORDS: China Luxi cattle, intramuscular preadipocyte, proliferation, differentiation, propionate

\footnotetext{
* Supported by The 948 Grant from Ministry of Agriculture of China with the Project No. 2003 - Z77

${ }^{1}$ Corresponding author: e-mail: qxmeng@cau.edu.cn
} 


\section{INTRODUCTION}

Beef marbling is characterized as intramuscular fat in a cross section of musculus longissimus. High levels of marbling improve the palatability and acceptability of beef by affecting the taste and tenderness of the meat (Nishimura et al., 1999). Intramuscular fat deposition involves a series of events that initiate and maintain preadipocyte proliferation, differentiation of in musculus longissimus (Albrecht et al., 2006).

It is well described that medium-chain fatty acids (MCFA) and long-chain fatty acids (LCFA) influenced rat preadipocytes and 3T3-L1 cells adipogenesis (Rentsch and Chiesi, 1996; Shintani et al., 2000; Han et al., 2002, 2003; Cammisotto et al., 2003). Recent evidences have suggested that short-chain fatty acids (SCFA) such as propionate can stimulate mouse preadipocytes differentiation (Hong et al., 2005). However, there are some conflicts in the regulative mechanisms of preadipocyte differentiation by fatty acids.

Ruminant animals ferment dietary carbohydrates into VFA by ruminal microorganisms, then use propionate as a primary precursor of gluconeogenesis. Therefore, propionate from rumen fermentation is largely associated with body fat deposition. Because little literature is available concerning the regulation of bovine intramuscular preadipocyte proliferation and differentiation by propionate, we design the present experiment to examine the effect of propionate on proliferation and differentiation of intramuscular preadipocytes from Chinese adult Luxi steers.

\section{MATERIAL AND METHODS}

Three Luxi adult Yellow steers (18 months of age) were used in this study. All procedures involving animals were conducted under the approval of the China Agricultural University Animal Care and Use Committee. Isolated preadipocytes were obtained using modified Aso's method (Aso et al., 1995). All preparations were performed under aseptic conditions, and all experiments were performed between the third and sixth passage and cultured in a $5 \% \mathrm{CO}_{2}$ humidified chamber at $37^{\circ} \mathrm{C}$.

Bovine intramuscular preadipocytes treated with propionate were analysed in flow cytometry. Briefly, cells were seeded in T- 25 flask at the density of $5 \times 10^{4}$ cells/ $\mathrm{cm}^{2}$ in growth medium supplemented with propionate at the concentration of 1,3 , and $6 \mathrm{mM}$. Media were changed every 2 days. Six days later, the treated cells were collected and suspended in the sterile tubes, and counted with a haemocytometer to determine cell number. Subsequently, the cells were permeabilized with $0.1 \%$ Triton X-100 in DPBS for 30 min at room temperature. Permeabilized cells were treated with $40 \mu \mathrm{g}$ of RNAse $/ \mathrm{ml}$ and then the DNA was immediately labelled with $100 \mu \mathrm{g} / \mathrm{ml}$ propidium iodide (PI)/ml before analysis. 
When cultured bovine intramuscular preadipocytes reached confluency (referred to day 0), the cells were further cultured in DMEM containing $10 \mu \mathrm{g} / \mathrm{ml}$ insulin, $0.25 \mu \mathrm{mol} /$ 1 dexamethasone, and serum-free (differentiation medium) for 2 days, and subsequently in fresh differentiation medium in the absence or presence of increasing concentrations of propionate. In order to determine the extent of preadipocytes differentiation at day 6 , both oil red $\mathrm{O}$ staining lipid droplets and cytoplasmic fat contents were determined using modified Ramirez-Zacarias' method (Ramirez-Zacarias et al., 1992).

Dulbecco's modified Eagle's medium (DMEM) and Dulbecco's PhosphateBuffered Saline (DPBS) were purchased from Gibco (Grand Island, NY). Bovine insulin, dexamethasone, collagenase, HEPES (powder), and propionate were supplied by Sigma-Aldrich Fine Chemical (St. Louis, MO, USA). Foetal bovine serum (FBS) was a product of PAA company (Austria). All other chemicals were locally from Beijing Chemical Reagent Company (China).

The data were subjected to a one-way analysis of variance using the GLM procedure of SAS (version 8.0, SAS Institute, Cary, NC) and the differences among the treatment means were tested with the procedure of STDERR and TDIFF.

\section{RESULTS}

To examine the effect of propionate on bovine intramuscular preadipocytes proliferation, the cells were treated with propionate for 6 days, and then the treated cells were collected for analysis by flow cytometry. Propionate at $1 \mathrm{mM}$ did not significantly $(\mathrm{P}>0.05)$ affect the cell proportion of phase $\mathrm{G} 0 / \mathrm{G} 1$, but remarkably $(\mathrm{P}<0.05)$ increased the proportion of phase $\mathrm{S}+\mathrm{G} 2 / \mathrm{M}$ compared with control group ( $0 \mathrm{mM}$ propionate). However, the cell proportion significantly increased $(\mathrm{P}<0.05)$ in the phase $\mathrm{G} 0 / \mathrm{G} 1$, and decreased $(\mathrm{P}<0.05)$ in the phase $\mathrm{S}+\mathrm{G} 2 / \mathrm{M}$ when the concentration of propionate reached to $6 \mathrm{mM}$ (Table 1). Furthermore, almost 90\% bovine preadipocytes treated with propionate remained in phase G0/G1 (result not shown).

Table 1. Influence of propionate on the proliferation of Luxi bovine intramuscular preadipocyte

\begin{tabular}{|c|c|c|c|c|c|}
\hline \multirow{2}{*}{ Item } & \multicolumn{4}{|c|}{ Propionate concentrations, $\mathrm{mM}$} & \multirow{2}{*}{$\mathrm{SE}$} \\
\hline & 0 & 1 & 3 & 6 & \\
\hline \multicolumn{6}{|l|}{$\begin{array}{l}\text { Cell cycle, \% } \\
\text { phase }\end{array}$} \\
\hline $\mathrm{G} 0 / \mathrm{G} 1$ & $92.30^{\mathrm{a}}$ & $91.77^{\mathrm{a}}$ & $92.96^{\mathrm{a}}$ & $95.29^{\mathrm{b}}$ & 0.53 \\
\hline $\mathrm{S}$ & 3.73 & 3.64 & 4.10 & 2.75 & 0.69 \\
\hline $\mathrm{G} 2 / \mathrm{M}$ & $3.98^{\mathrm{ab}}$ & $4.60^{\mathrm{ab}}$ & $2.95^{\mathrm{bc}}$ & $1.96^{\mathrm{c}}$ & 0.46 \\
\hline$(\mathrm{S}+\mathrm{G} 2 / \mathrm{M})$ & $7.71^{\mathrm{a}}$ & $8.24^{\mathrm{a}}$ & $7.05^{\mathrm{a}}$ & $4.70^{\mathrm{b}}$ & 0.53 \\
\hline
\end{tabular}

${ }^{a, b}$ within a row means with different superscripts differ $(\mathrm{P}<0.05)$

The cell cycle is generally considered to be composed of four phases, namely the gap prior to DNA replication (G1), the synthetic phase (S), the gap after DNA (G2) and mitosis (M), and quiescent or noncycling cells would be considered in G0 (Hartwell et al., 1989) 
To investigate the effect of propionate on bovine intramuscular preadipocytes differentiation, we determined cytoplasmic fat contents of the cells treated with propionate for 6 days and stained cytoplasmic lipid droplets with oil red O. After the confluent cells were treated with $10 \mu \mathrm{g} / \mathrm{ml}$ insulin and $0.25 \mu \mathrm{M}$ dexamethasone, small lipid droplets began to appear on day 2 (results not shown) and the number of lipid droplets rapidly increased around the nuclei on day 6 (Figure 1A,B,C). When the cells were treated with propionate, significant accumulation of cytoplasmic lipid droplets was observed at day 6 (Figure 1D,E,F), and lipid accumulation extent was dependent on the dose of propionate. In addition, cytoplasmic fat contents of cultured preadipocytes with the treatment of propionate $(1,3,6 \mathrm{mM})$ for 6 days were $1.5,2$, and 2 times higher than that of propionate at $0 \mathrm{mM}$ (Table 2).

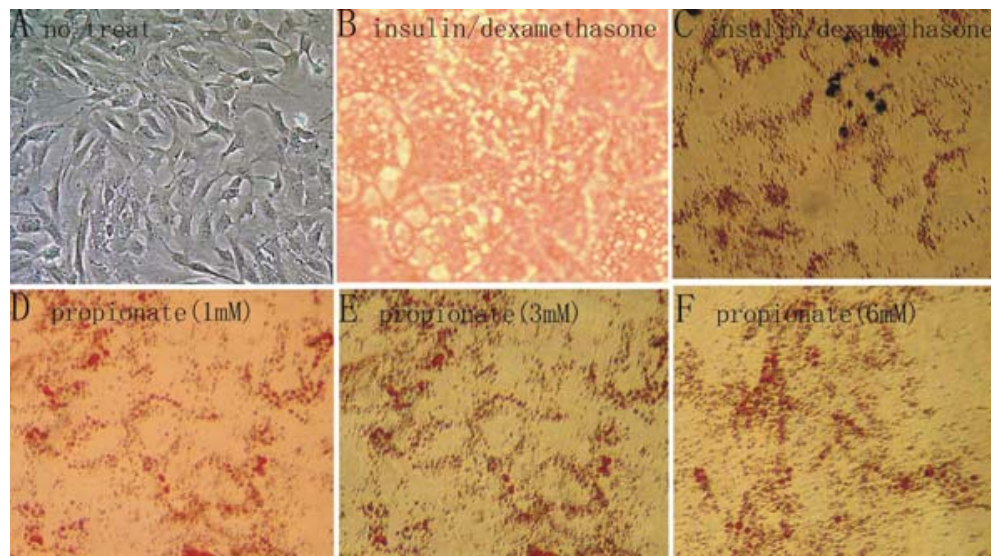

Figure 1. Morphological changes of bovine intramuscular preadipocyte differentiation stimulated by propionate. (A) The cells were not treated with propionate. Bovine intramuscular preadipocytes were treated with insulin $(10 \mu \mathrm{g} / \mathrm{ml})$ and dexamethasone $(0.25 \mu \mathrm{mol} / \mathrm{l})$ for 6 days after confluence, intracellular lipid was not (B) or stained (C) with oil red O. Cells on day 6 after being induced to differentiation in the presence of $1 \mathrm{mM}(\mathrm{D}), 3 \mathrm{mM}(\mathrm{E})$, and $6 \mathrm{mM}(\mathrm{F})$ propionate. Bar $=100 \mu \mathrm{m}$

Table 2. Changes of cytoplasmic fat content in Luxi bovine intramuscular preadipocyte differentiation by propionate

\begin{tabular}{lllllll}
\hline \multirow{2}{*}{ Item } & \multicolumn{5}{c}{ Propionate concentrations, mM } & \multirow{2}{*}{ SE } \\
\cline { 2 - 5 } & \multicolumn{1}{c}{0} & \multicolumn{1}{c}{1} & 3 & \multicolumn{1}{c}{6} & \\
\hline Sample numbers, $\mathrm{n}^{*}$ & 7 & 8 & 8 & 8 & \\
OD value*, per well & $0.023^{\mathrm{a}}$ & $0.034^{\mathrm{b}}$ & $0.041^{\mathrm{bc}}$ & $0.044^{\mathrm{bc}}$ & 0.004 \\
\hline
\end{tabular}

${ }^{a, b, c}$ within a row means with different superscripts differ $(\mathrm{P}<0.05)$

* indicated the cells treated with propionate were always seeded in 24-well plates at the density of $5 \times 10^{4}$ cells $/ \mathrm{cm}^{2}$, and OD Value was determined to collect the number of cells per well 


\section{DISCUSSION}

In the present study, we demonstrated the effects of propionate on the proliferation and differentiation of bovine preadipocytes in vitro.

In our experiments, propionate at $1 \mathrm{mM}$ did not significantly affect the cell proportion of phase $\mathrm{S}+\mathrm{G} 2 / \mathrm{M}$, and almost $90 \%$ bovine preadipocytes treated with propionate remained in the phase $\mathrm{G} 0 / \mathrm{G} 1$. S+G2/M refers to the extent of cell proliferation. The above results indicated that propionate at the appropriate concentration is in favour of preadipocytes proliferation. In addition, adipose tissue is mainly composed of matured adipocytes. So it indirectly enhances the potential of intramuscular fat deposition. When the confluent cells were treated with propionate for 6 days, $1 \mathrm{mM}$ propionate significantly increased intracellular fat contents of bovine intramuscular preadipocytes. Nevertheless, intracellular fat contents almost failed to rise when the cells were treated with propionate at the concentration of 3 or $6 \mathrm{mM}$. Short-chain fatty acids stimulate leptin production in adipocytes (Xiong et al., 2004) and fatty acids with a chain length superior or equal to eight carbons effectively inhibited insulin-stimulated leptin secretion (Cammisotto et al., 2003). Leptin mainly produced in adipose tissue. These data suggest that volatile fatty acids within their physiological levels (total $\sim 1 \mathrm{mM}$ ) may only promote adipogenesis (Quigley et al., 1991). Plasma leptin levels are likely to regulate propionate homeostasis in ruminants by a feedback mechanism. The above results also remind us that the production of VFA, especially propionic acid, is important to ruminants. So it is essential for us to regulate the production of VFA and proportion of VFA. Moreover, it is useful for us to further understand the mechanism by which the intramuscular adipose is deposed in the tissues, and improve the beef quality in local beef cattle breed.

\section{CONCLUSIONS}

Propionate significantly promoted bovine intramuscular preadipocyte proliferation and differentiation. With incremental propionate concentration, cytoplasmic fat contents of cultured preadipocytes were increased, indicating a dose dependent manner with propionate addition. Further studies are required to clarify a signal transduction mechanism of propionate in adipogenesis. 


\section{REFERENCES}

Albrecht E., Teuscher F., Ender K., Wegner J., 2006. Growth- and breed-related changes of marbling characteristics in cattle. J. Anim. Sci. 84, 1067-1075

Aso H., Abe H., Nakajima N., Ozutsumi K., Yamaguchi T., Takamori Y., Kodama A., Hoshino F.B., 1995. A preadipocyte clonal line from bovine intramuscular adipose tissue: nonexpression of GLUT-4 protein during adipocyte differentiation. Biochem. Biophys. Res. Commun. 213, 369375

Cammisotto P.G., Gelinas Y., Deshaies Y., Bukowiecki L.J., 2003. Regulation of leptin secretion from white adipocytes by free fatty acids. Amer. J. Physiol. Endocrinol. Met. 285, E521-E526

Han J., Farmer S.R., Kirkland J.L., Corkey B.E., Yoon R., Pirtskhalava T., 2002. Octanoate attenuates adipogenesis in 3T3-L1 preadipocytes. J. Nutr. 132, 904-910

Han J., Hamilton J.A., Kirkland J.L., Corkey B.E., Guo W., 2003. Medium-chain oil reduces fat mass and down-regulates expression of adipogenic genes in rats. Obes. Res. 11, 734-744

Hartwell L.H., Weinert T.A., 1989. Checkpoints: controls that ensure the order of cell cycle events. Science 246, 629-634

Hong Y.-H., Nishimura Y., Hishikawa D., Tsuzuki H., Miyahara H., 2005. Acetate and propionate short chain fatty acids stimulate adipogenesis via GPCR43. Endocrinology 146, 5092-5099

Nishimura T., Hattori A., Takahashi K., 1999. Structural changes in intramuscular connective tissue during the fattening of Japanese Black cattle: effect of marbling on beef tenderization. J. Anim. Sci. 77, 93-104

Quigley J.D., Smith Z.P., Heitmann R.N., 1991. Changes in plasma volatile fatty acids in response to weaning and feed intake in young calves. J. Dairy Sci. 74, 258-263

Ramirez-Zacarias J.L., Castro-Munozledo F., Kuri-Harcuch W., 1992. Quantitation of adipose conversion and triglycerides by staining intracytoplasmic lipids with oil red O. Histochemistry 97, 493-497

Rentsch J., Chiesi M., 1996. Regulation of $o b$ gene mRNA levels in cultured adipocytes. FEBS Lett. 379, 55-59

Shintani M., Nishimura H., Yonemitsu S., Masuzaki H., Ogawa Y., Hosoda K., 2000. Downregulation of leptin by free fatty acids in rat adipocytes: effects of triacsin C, palmitate, and 2-bromopalmitate. Metabolism 49, 326-330

Xiong Y., Miyamoto N., Shibata K., 2004. Short-chain fatty acids stimulate leptin production in adipocytes through the G protein-coupled receptor GPR41. Proc. Nat. Acad. Sci. USA 101, 1045-1050 